Olga Jastrzębska

ORCID: 0000-0001-6476-7073

Uniwersytet Wrocławski

\title{
Znaczenie przestrzeni w procesie kształtowania państwa rosyjskiego
}

\author{
DOI: $10.19195 / 1643-0328.25 .9$
}

Słowa kluczowe: przestrzeń, strefy buforowe, kolonizacja, ekspansja terytorialna

W procesach tworzenia i kształtowania zjawisk społecznych jedną z głównych ról odgrywa czynnik przestrzenny. Zjawisko przestrzeni często było motorem i głównym budulcem wielu procesów, mających wpływ na funkcjonowanie państw i społeczeństw. Niektóre $\mathrm{z}$ nich traktowały przestrzeń jako swój główny atut, wykorzystywany w toku formowania ich polityki zagranicznej i wewnętrznej.

Jednym z państw, traktujących przestrzeń jako czynnik kreujący najistotniejsze procesy ekonomiczne, społeczne i polityczne, jest Rosja. Głównym celem artykułu jest ukazanie roli, jaką pełniła przestrzeń w przeszłości, a także w czasach obecnych, w procesie kreowania polityki tego państwa, ze szczególnym uwzględnieniem odpowiedzi na pytanie, które jej rodzaje - materialne (najczęściej rozumiane jako przestrzeń fizyczna) czy niematerialne (jak przestrzeń społeczna czy kulturowa) — odegrały ważniejszą rolę i jaki typ przestrzeni można uznać dla Rosji za najistotniejszy. Warto zastanowić się także nad obecną rolą tego zjawiska w kształtowaniu polityki rosyjskiej, zwłaszcza pod kątem poszczególnych jej typów - czy są one motorem czy hamulcem jej rozwoju.

\section{Pojęcie przestrzeni}

Próba zdefiniowania pojęcia przestrzeni jest niezwykle trudna ze względu na fakt odmiennego postrzegania jej istoty. Można wyróżnić dwa najważniejsze typy kształtowania jej określeń: postrzeganie przestrzeni jako nieruchomego stanu lub jako zjawiska procesualnego. 
Pierwsza koncepcja traktuje przestrzeń jako statyczną płaszczyznę, będącą lokalizacją wszelkich fizycznych zjawisk ${ }^{1}$. Jest ona swoistym tłem dla rozgrywających się w niej wydarzeń i kreujących je bytów oraz ich warunkiem koniecznym - każdy element musi być $\mathrm{w}$ tej przestrzeni umiejscowiony ${ }^{2}$. Przynależność do określonej części tego nieograniczonego obszaru jest wspólną właściwością wszystkich istniejących obiektów.

Druga koncepcja postrzega przestrzeń jako rezultat relacji istniejących między materialnymi obiektami, ich cechami oraz rozmieszczeniem ${ }^{3}$. Model ten określany jest jako relacyjna koncepcja przestrzeni ${ }^{4}$. Mimo wyraźnej dominacji człowieka przestrzeń nie jest elementem zupełnie biernym, gdyż umiejscowienie podmiotów jest jednym z elementów kształtujących ich późniejsze relacje. Wszystkie części procesu kreacji przestrzeni w tym ujęciu oddziałują na siebie, dzięki czemu proces jej tworzenia nie jest statyczny - nowe przestrzenie są ciągle tworzone. Dynamiczne relacje nadają kształtowanej przez nie przestrzeni ruchliwość i elastyczność, przez co jest ona zjawiskiem będącym w stanie przystosować się do wszelkich modyfikacji ${ }^{5}$.

Przestrzeń różnicowana jest także na podstawie sposobów jej kreacji, głównym punktem odniesienia jest zaś w tym wypadku człowiek, który jest instrumentem tworzącym ją i nadającym jej najważniejsze cechy. W tym ujęciu można wyróżnić przestrzenie istniejące samoistnie oraz ich odpowiedniki kształtowane przez człowieka. Przestrzenią egzystująca samoistnie jest przestrzeń fizyczna, a jej ekwiwalentami kreowanymi przez ludzi są dla przykładu przestrzeń społeczna lub egzystencjalna. Podział ten nie tylko odwzorowuje konkretny sposób tworzenia przestrzeni, ale pozwala też na głębsze zrozumienie ich wzajemnego stosunku oraz relacji z człowiekiem.

Przestrzenie istniejące samoistnie można nazwać pierwotnymi, gdyż są tworzone bez udziału człowieka i mogą funkcjonować bez niego. Najlepszym przykładem może być newtonowska koncepcja przestrzeni absolutnej, posiadającej możliwość egzystencji bez istniejącej w niej materii ${ }^{6}$. W relacjach $\mathrm{z}$ jednostką ludzką przestrzenie te mają z reguły pozycję dominującą i narzucają jej określone reguły postępowania.

Henri Lefebrve stwierdził, że przestrzeń fizyczna jest wstępnym warunkiem do produkcji relacji społecznych ${ }^{7}$, czyli bazą dla procesu tworzenia przez społeczeństwo swoich własnych przestrzeni. Pierwszą przestrzenią, z którą styka się człowiek po narodzinach, jest przestrzeń fizyczna, służąca następnie do budowy jego przestrzeni egzystencjalnej. Ich suma na określonym obszarze jest fundamentem kolejnej przestrzeni, z którą jed-

1 A. Lisowski, Typy przestrzeni a geografia, „Prace Komisji Obszaru Krajobrazu Kulturowego” 2014, nr 24, s. 11.

2 Z.E. Roskal, Koncepcje przestrzeni w filozofii przyrody, „Roczniki Filozoficzne” 56, 2008, nr 1, s. 281.

3 A. Mejer, Socjologia i przestrzeń miejska, Warszawa 2010, s. 21.

4 A. Bukowski, M. Lubaś, J. Nowak, Społeczne tworzenie miejsc - globalizacja, etniczność, władza, Kraków 2010, s. 7.

5 D. Massey, Politics and space/time, „New Left Review” 1992, I/196, s. 80-81.

6 D. Harvey, Space as a key word, referat wygłoszony na Marx and Philosophy Conference 20 maja 2004 w Institute of Education w Londynie, dostępny na stronie http://www.frontdeskapparatus.com/files/ harvey2004.pdf (dostęp: 6.02.2018), s. 2-4.

7 Ch. Butler, Critical legal studies and the politics of space, „Social and Legal Studies” 18, 2009, nr 3, s. 13. 
nostka ma styczność - przestrzeni społecznej. Można wysnuć wniosek, iż przestrzenie istniejące samoistnie, egzemplifikowane poprzez przestrzeń fizyczną, są punktem wyjścia przestrzeni kreowanych przez człowieka, który przyswaja ją i adaptuje odpowiednio do swoich potrzeb.

Wśród przestrzeni tworzonych przez człowieka warto zdefiniować przestrzeń społeczną. Finalny jej kształt jest formułowany przez jednostkę ludzką i jej użytkowanie ${ }^{8}$. Obydwa fenomeny są punktem wyjścia innych rodzajów przestrzeni, np. cywilizacyjnej czy kulturowej. Znakiem czasów jest tworzenie przez człowieka nowych przestrzeni, będących rezultatem rozwoju nauki (przestrzeń wirtualna). Relacje między tymi przestrzeniami polegają $\mathrm{w}$ dużej mierze na wzajemnym powiązaniu i koegzystencji. W ramach przestrzeni kulturowej zawarta jest przestrzeń historyczna, obydwie są zaś częścią szeroko rozumianej przestrzeni cywilizacyjnej. Niektóre przestrzenie wzajemnie warunkują się - przestrzeń konceptualna, rozumiana jako lokowanie i porządkowanie wartości, przejawiająca się najczęściej w postaci różnych idei lub koncepcji działania, jest podstawą przestrzeni pragmatycznej, mieszczącej w sobie aktywność ludzką, wdrażającą wspomniane idee w życie 9 .

Krótka analiza rodzajów przestrzeni, ich charakterystycznych cech oraz współzależności pomaga odpowiedzieć na pytanie, czym ona jest. Mimo przyjmowania przez nią różnych kształtów i znaczeń może być nazwana stykiem elementów materialnych i niematerialnych, czyli stanem, któremu człowiek nadaje określone znaczenie, mogące przybierać postać sieci relacji społecznych, systemu regulacji prawnych lub nieruchomej areny. Jednak to człowiek tworzy sens, który je konkretyzuje i pozwala na ustalenie ich najważniejszych cech. Nawet przestrzenie istniejące samoistnie, które nie potrzebują człowieka, by egzystować, są przez niego wyposażane w określone znaczenie, warunkujące ich postrzeganie. Według G. Simmla bez człowieka przestrzeń nie posiada żadnej określonej treści ${ }^{10}$, gdyż to on nadaje ją formom mogącym istnieć nawet w sposób od niego samodzielny. Egzemplifikacją nadawania przez człowieka znaczeń konkretnym stanom zetknięcia elementów materialnych i niematerialnych są różne rodzaje przestrzeni, odgrywające główną rolę na gruncie poszczególnych nauk. W wypadku socjologii jest to przestrzeń społeczna, dla nauki o stosunkach międzynarodowych - konceptualna, dla nauk prawnych - prawna itp. Ich różnorodność odzwierciedla mnogość znaczeń, które człowiek może wykorzystać w celu deskrypcji tego zjawiska.

Analiza wykorzystania przestrzeni w konkretnym przypadku - polityki państwa rosyjskiego - pokazuje, że czynnik ten może zdominować proces tworzenia stabilnych instytucji państwowych, społecznych i ekonomicznych. Czy jednak główną rolę w przytaczanym casusie odegrała wyłącznie przestrzeń w jej fizycznym, materialnym rozumieniu? Jaką rolę spełniały jej niematerialne odpowiedniki i który z rodzajów przestrzeni był najistotniejszy?

8 A. Mejer, op. cit., s. 43-44.

9 A. Gałganek, Przestrzenny obraz świata w nauce o stosunkach międzynarodowych, „Sprawy Międzynarodowe" 1989, nr 3, s. 97.

10 C. Javeau, Przestrzeń jako forma społeczna, forma życia, próba odnowienia koncepcji wedlug R. Lerduta, A. Schutza i G. Simmla, [w:] Przestrzeń znaczaca. Studia socjologiczne, red. J. Wódz, Katowice 1989, s. 54. 


\section{Rola przestrzeni w polityce wewnętrznej Rosji}

Stosunek Rosjan do przestrzeni w znaczeniu fizycznym, czyli terytorium ich państwa, nazwać można specyficzną mieszaniną przywiązania i strachu. Na odbiór opisywanego zjawiska miały bez wątpienia wpływ jego cechy geograficzne: przewaga bezkresnego, nizinnego krajobrazu oraz brak wyraźnie oznaczonych granic. Owa amorficzność była przyczyną swoistej uległości i pokory Rosjanina wobec przestrzeni, przytłaczającej go swoją wielkością. Jednocześnie ogromne przestrzenie były odbierane przez Rosjan jako bezpieczne schronienie przed wszelkimi zagrożeniami płynącymi z zewnątrz ${ }^{11}$. Rosjanin niejako „oddawał się w opiekę” przestrzeni. Specyficzny stosunek Rosjan do władzy, pełen podporządkowania i strachu, jest pochodną ich relacji z przestrzenią. Zapanować nad tym bezkresem można było tylko przez silne i scentralizowane rządy. Mieszkańcy Rosji byli gotowi podporządkować się władzy, gdyż to właśnie państwo poprzez organizację swoich struktur na wielkich obszarach przyczyniało się do oswojenia i wykorzystania przestrzeni ${ }^{12}$.

Pełen szacunku stosunek Rosjan do przestrzeni przyczynił się także do postrzegania jej jako wartości, która - odpowiednio zagospodarowana - może być wykorzystana przez państwo na wielu płaszczyznach. Ta zależność była szczególnie widoczna na polu bezpieczeństwa, gdzie przestrzeń pełniła podwójną rolę — była zarówno zagrożeniem, jak i środkiem defensywnym. Brak wyraźnie określonych granic oraz nizinne w większości ukształtowanie powierzchni zwiększały prawdopodobieństwo najazdów z zewnątrz. Wyzwalało to psychologiczne poczucie permanentnego zagrożenia, które musiało być zniwelowane poprzez konkretne działania ${ }^{13}$.Zaliczyć do nich można poszerzanie zakresu swoich przestrzeni, najczęściej kosztem krajów sąsiednich, w celu zapobieżenia ekspansji potencjalnych wrogów. Podporządkowanie krajów Europy Środkowo-Wschodniej służyło powstrzymaniu ekspansji Niemiec, próby podboju Afganistanu miały zaś być przeciwwagą dla potęgi Wielkiej Brytanii. Rosja nie poprzestawała tylko na terytorialnych zaborach, lecz wykorzystywała podbite ziemie w celu umacniania swojego bezpieczeństwa, m.in. przez tworzenie stref buforowych: ziemie polskie miały chronić Rosję przed działaniami Niemiec, a państwa bałtyckie przed atakiem Szwecji. Była to strategia umocnienia poczucia bezpieczeństwa przez ekspansję terytorialną.

Równie istotną rolę w historii Rosji odegrała przestrzeń na polu stosunków gospodarczych. Jej wykorzystanie, podobnie jak w przypadku obronności, podyktowane było $\mathrm{m}$.in. warunkami przyrodniczymi. Surowy klimat w połączeniu z ekstensywnym i przestarzałym sposobem gospodarowania ziemią powodował niską efektywność rosyjskiego rolnictwa. Jedyną możliwością jej zwiększenia okazywało się często powiększanie areału upraw. Implikowało to konieczność zdobywania nowych obszarów. Była to także istotna

11 S. Medvedev, A General Theory of Russian Space: A Gay Science and the Rigorous Science, [w:] Beyond the Limits. The Concept of Space in Russian History and Culture, red. J. Smith, Helsinki 1999, s. 17, 195.

12 M. Bierdajew, O władzy przestrzeni nad rosyjska dusza, [w:] Niemarksistowska filozofia rosyjska. Antologia tekstów filozoficznych XIX i pierwszej połowy XX wieku. Część I, red. L. Kiejzik, Łódź 2011, s. 195.

13 R. Kaplan, The Revenge of Geography. What the Map Tells Us about Coming Conflict and the Battle against Fate, Toronto 2012, s. 159. 
przyczyna podboju i kolonizacji nowych terytoriów. Rozpoczęte w XVI w. opanowywanie Syberii służyło nawiązaniu kontaktów handlowych z ludami zamieszkującymi tę krainę. Przypadający na XIX w. zabór ziem Azji Środkowej podyktowany był koniecznością pozyskania obszarów pod uprawę bawełny ${ }^{14}$. Podobnie jak w wypadku kwestii obronności, rozszerzanie terytorium państwa wymuszone było konkretnymi względami - poszerzeniem ekonomicznych wpływów, przyczyniających się do zwiększenia rozwoju gospodarczego, oraz kreowaniem niezwykle ważnej dla Rosji przestrzeni geoekonomicznej.

Przestrzeń, bazująca ściśle na wpływach i interesach, przyczyniała się do umocnienia pozycji Rosji w Europie i Azji oraz miała wpływ na kształtowanie rosyjskiej wizji porządku świata. Rosyjscy decydenci zaczęli postrzegać państwa sąsiednie jako swoją strefę wpływów. Proces kształtowania rosyjskiej przestrzeni geoekonomicznej ${ }^{15}$, rozpoczęty w czasach carskich, kontynuowany był w okresie sowieckim, czego najlepszym przykładem była radziecka strefa wpływów, składająca się z państw Europy Środkowo-Wschodniej oraz niektórych krajów pozaeuropejskich.

Przestrzeń odegrała także bardzo ważną rolę w zakresie kształtowania rosyjskiego społeczeństwa. Na przełomie XIX i XX w. służyła jako narzędzie do rozwiązywania problemów demograficznych państwa. Najważniejszym z nich było przeludnienie panujące w europejskiej części kraju. Rozwiązaniem było osiedlanie rodzin chłopskich na niezagospodarowanych do tej pory syberyjskich ziemiach, w celu włączenia ich w system gospodarczy Cesarstwa ${ }^{16}$. Szeroko zakrojona akcja kolonizacyjna spowodowała, że na obszar Syberii przesiedlono w latach $1896-1916$ ok. 4 mln ludzi ${ }^{17}$. Był to przykład kolonizacji wewnętrznej, wykorzystania przestrzeni jako narzędzia zwiększającego ekonomiczną produktywność rolnictwa oraz jednoczącego odległe ziemie z resztą kraju ${ }^{18}$. Podjęta przez rosyjskich decydentów decyzja o rozpoczęciu procesu osadnictwa miała na celu opanowanie rozległych przestrzeni i przekształcenie ich z ciężaru w czynnik sprzyjający rozwojowi gospodarczemu.

Przestrzeń wykorzystywana była także jako swoiste narzędzie inżynierii społecznej, mające służyć budowie systemu autorytarnego, przybierającego w czasach radzieckich formę totalitarną. W celu realizacji tej funkcji podejmowane były różne działania, jak przesiedlenia ludności czy tworzenie miejsc odosobnienia. Podejmowane przez władze rosyjskie działania można nazwać wykorzystaniem przestrzeni w celu zwalczania przeciwnika, zagrażającego budowie nowego, podporządkowanego władzy społeczeństwa ${ }^{19}$.

14 W. Zajączkowski, Rosja i narody. Ósmy kontynent. Szkic dziejów Eurazji, Warszawa 2015, s. 37-38, $41-42$.

15 W.J. Rogov, Osnovy formirovanija geoekonomiczieskich regionov sovriemiennoi Rossiji, Irkutsk 2002, s. $21-22$.

16 W.B. Lincoln, The Conquest of the Continent: Siberia and the Russians, Ithaca 2007, s. 256.

17 A. Etkind, Internal Colonization: Russia's Internal Experience, Cambridge 2011, s. 71.

18 A. Remnev, Siberia and the Russian Far East in the Imperial Geography of Power, [w:] J. Burbank, M. von Hagen, A.V. Remnev, Russian Empire: Space, People, Power, Bloomington 2007, s. 431.

19 K.E. Aksenov, Prostranstvo i politika. Konceptualnyje podchody i izuczienije osobnoi priedmietnoi oblasti, Sankt Petersburg 1993, s. 25. 
Przesiedlenia ludności stosowane były już w czasach Wielkiego Księstwa Moskiewskiego - po zdobyciu Pskowa w roku 1510 wielki książę Wasilij III kazał wysiedlić do Moskwy 300 pskowskich rodzin ${ }^{20}$. Podobną metodę zastosował w XX w. Józef Stalin, nakazując przesiedlenia całych narodów podejrzewanych o nielojalność w stosunku do radzieckiej władzy. Wykorzystano w tym celu instytucję „specjalnego osiedlenia”, czyli de facto połączenia deportacji z ograniczeniem ruchliwości przestrzennej w nowym miejscu pobytu $^{21}$. Bezkres i rozległość syberyjskich przestrzeni były także idealnym czynnikiem pozwalającym na wykorzystanie ich w charakterze miejsca odosobnienia. Od $1539 \mathrm{r}$. Syberia była obszarem zsyłek i umiejscowieniem systemu obozów pracy przymusowej ${ }^{22}$.

Wymienione migracje przyczyniły się do powstania wielu nowych przestrzeni, kreowanych nie tylko przez migrujących z własnej woli chłopów, ale także przez grupy narodowościowe przesiedlane przymusowo, jak społeczność polska w Kazachstanie. Wspólnoty te kształtowały swoje kulturowe przestrzenie, dostosowując się do narzuconych im warunków i jednocześnie kultywując zwyczaje wyniesione z kraju pochodzenia. Przestrzeń w ramach kształtowania rosyjskiej polityki wewnętrznej nie tylko była instrumentem wykorzystywanym w procesie jej kreacji, ale też jej rezultatem.

\section{Rola przestrzeni w polityce zagranicznej Rosji}

Poszczególne rodzaje przestrzeni odgrywają też istotną rolę na gruncie rosyjskiej polityki zagranicznej. Egzemplifikacją takiego stanu, bazującego na wykorzystaniu przestrzeni ekonomicznej, jest ukształtowanie własnego ugrupowania integracyjnego - Eurazjatyckiej Unii Gospodarczej (EUG), powstałej na gruncie istniejącej od roku 2007 Unii Celnej. Skupiająca obecnie 5 państw (Rosja, Białoruś, Kazachstan, Armenia oraz Kirgistan) organizacja zakłada umocnienie więzi gospodarczych między nimi ${ }^{23}$ oraz usuwanie barier na tym polu. Jest ona podstawowym instrumentem pozwalającym utrzymać rosyjską dominację w zakresie politycznym oraz ekonomicznym. Jako przykład przewagi gospodarczej może służyć ekspansja rosyjskich produktów na rynki pozostałych państw członkowskich, np. maszyn, stanowiących według słów prezydenta Putina 10\% eksportu rosyjskiego do krajów EUG. W praktyce oznacza to narzucanie własnych produktów, nie zawsze wysokiej jakości ${ }^{24}$. Moskwa udziela upustów cenowych także w negocjacjach

20 W.M. Marasanova, Istorija Rossiji do konca XVII stoletija, Moskwa 2013, s. 116.

${ }^{21}$ M. Łożeński, Ekspansja na wszystkich azymutach: od Rurykowiczów po gesneków, Warszawa 1987, s. $42-43$.

22 P. Fryer, Heaven, Hell or...? Something in between? Contrasting Russia Images of Syberia, [w:] Beyond the Limits..., s. 99-100.

${ }^{23}$ P. Świeżak, Unia Celna - między mirażem „Wschodniej Unii Europejskiej” a widmem „nowego ZSRR”, „Bezpieczeństwo Narodowe” 2013, nr 28, s. 19.

${ }^{24}$ O. Jastrzębska, Geoekonomiczne motywy działania Rosji względem Ukrainy, „Ante Portas. Studia nad Bezpieczeństwem" 2015, nr 2 (5), s. 146. 
z państwami, których polityka zagraniczna jest dla niej korzystna ${ }^{25}$, co tylko utwierdza je w przekonaniu o opłacalności współpracy ze stroną rosyjską. Poprzez poszerzanie przestrzeni ekonomicznej Moskwa umacnia jednocześnie przestrzeń swoich wpływów politycznych, co pokazuje desygnowanie w roku 2016 na stanowisko premiera Armenii byłego menedżera Gazpromu ${ }^{26}$.

Równie istotną rolę w opisywanym przypadku odgrywa przestrzeń społeczna, połączona $\mathrm{z}$ silnym akcentowaniem przestrzeni symbolicznej. Kształtowana jest w oparciu o „Russkij mir” - liczącą ok. 20 mln osób wspólnotę Rosjan, zamieszkałych nie tylko w Rosji, ale też innych krajach byłego ZSRR ${ }^{27}$. Charakterystycznymi czynnikami łączącymi tę wspólnotę są język rosyjski, religia prawosławna oraz wspólna przeszłość historyczna, odwołująca się do dziedzictwa Rosji carskiej i ZSRR. Federacja Rosyjska utrzymuje $\mathrm{z}$ nią intensywny kontakt, m.in. poprzez wspieranie ich organizacji kulturalnych, oświatowych oraz politycznych (np. działającą na Krymie Rosyjską Wspólnotę Sewastopola ${ }^{28}$ ). Dzięki aktywności rosyjskiej diaspory Moskwa może wywierać realny wpływ na sytuację polityczną w tych państwach oraz ingerować w ich wewnętrzne sprawy, najczęściej pod pretekstem obrony praw mniejszości rosyjskiej. Organizacje Rosjan w byłych republikach radzieckich przyczyniają się do kształtowania na terenach państw, w których działają, własnej przestrzeni społecznej, często niezależnej i egzystującej w oderwaniu od miejscowego środowiska. Ilustracją takiego stanu rzeczy są preferencje młodych Rosjan zamieszkujących Estonię, dotyczące środków masowego przekazu $92 \%$ z nich ogląda wyłącznie rosyjskie kanały telewizyjne ${ }^{29}$, przez co ich światopogląd pokrywa się w dużej mierze z obrazem świata, kształtowanym przez Moskwę. Osobnym czynnikiem jest także przestrzeń religijna, która jednoczy mieszkających za granicą Rosjan wokół wartości, często utożsamianych z rosyjskością, służy również podtrzymywaniu więzi z Moskwą w innych prawosławnych państwach, jak Białoruśs ${ }^{30}$. Dzięki działaniom Cerkwi umacniany jest w tych krajach obraz Rosji jako państwa bliskiego kulturowo, będącego naturalnym sojusznikiem i partnerem integracyjnym. Tworzona przez Rosjan zamieszkujących republiki byłego ZSRR przestrzeń społeczna i kulturowa pozwala na wywieranie nacisków na władze tych państw, mogących przyczynić się do poważnych zaburzeń w ich funkcjonowaniu, co można było zaobserwować na przykładzie kryzysu

25 A. Michalik, Unia Eurazjatycka - realna szansa dla integracji gospodarczej $w$ regionie, „Studia Ekonomiczne. Zeszyty Naukowe UE w Katowicach” 2015, nr 228, s. 41.

26 A. Kublik, Premierem Armenii zostat menadżer Gazpromu, http://wyborcza.pl/1,155290,20685257,premierem-armenii-zostal-menedzer-gazpromu.html (dostęp: 20.11.2017).

27 G. Pawlikowski, Mniejszość rosyjska jako instrument polityki zagranicznej Federacji Rosyjskiej po $1991 \mathrm{roku}$, http://geopolityka.net/grzegorz-pawlikowski-mniejszosc-rosyjska-jako-instrument-polityki-z agranicznej-federacji-rosyjskiej/ (dostęp: 1.01.2018).

28 P. Andrusieczko, Problem Krymu w relacjach rosyjsko-ukraińskich, [w:] Rosja. Między imperium a mocarstwem nowoczesnym, red. A. Dudek, R. Mazur, Toruń 2010, s. 224.

29 M. Kosienkowski, Strategia adaptacyjna Federacji Rosyjskiej wobec państw battyckich, Toruń 2006, s. 107.

30 A. Curanovic, Dyplomacja konfesyjna Federacji Rosyjskiej, [w:] Rosja. Między imperium a mocarstwem nowoczesnym..., s. 156-157. 
krymskiego. Doniosłość znaczenia tej przestrzeni podkreślił sam minister Ławrow, nazywając wsparcie dla rosyjskiej diaspory bezwzględnym priorytetem ${ }^{31}$.

Innym rodzajem przestrzeni, której znaczenie dla Rosji wzrosło w obecnych czasach, jest przestrzeń informacyjna. Zdefiniowana została ona w Koncepcji działalności Sit Zbrojnych Federacji Rosyjskiej w przestrzeni informacyjnej jako działalność bazująca na kształtowaniu, przekazywaniu i wykorzystywaniu informacji, które mogą wpływać na świadomość indywidualną, społeczną oraz infrastrukturę informacyjną ${ }^{32}$. W celu umocnienia swojej pozycji międzynarodowej Rosja wykorzystuje ją zarówno na polu polityki wewnętrznej, jak i zagranicznej. Zabiegi te mają miejsce w tradycyjnym obiegu informacyjnym, jak prasa czy telewizja, ale także w intensywnie rozwijającej się cyberprzestrzeni, czyli internecie. Na polu polityki wewnętrznej ich celem jest konsolidacja społeczeństwa wokół obozu rządzącego oraz przeciwdziałanie rozwojowi sił opozycyjnych, na polu polityki zagranicznej - kreowanie pozytywnego wizerunku Rosji za granicą oraz pozyskiwanie sojuszników dla prowadzonej polityki. Formą tych działań jest m.in. tworzenie „alternatywnych” portali internetowych, propagujących bieżące działania Rosji oraz rozprowadzających fałszywe informacje. Wykorzystywanie przestrzeni informacyjnej przez Rosję w wyżej opisywanym celu było szczególnie widoczne w Czechach, gdzie powstało kilkadziesiąt portali propagandowych, służących gloryfikacji polityki Moskwy. Docierały one do znacznej liczby odbiorców - 25\% Czechów przyznało, że uznaje znajdujące się na nich informacje za prawdziwe ${ }^{33}$.

Drugim - obok internetu — ważnym instrumentem oddziaływania Rosji na opinię publiczną innych państw są tworzone przez nią kanały telewizyjne nadawane w wielu krajach europejskich, jak Gołos Rossiji czy Russia Today (RT) ${ }^{34}$. Prezentowane informacje kształtują punkt widzenia odbiorcy na różne sposoby, m.in. poprzez zapraszanie na antenę RT w Holandii miejscowych „ekspertów”, prezentujących poglądy jawnie prorosyjskie ${ }^{35}$, lub atakowanie podczas kampanii wyborczych polityków niesprzyjających Moskwie, jak w przypadku E. Macrona podczas jego kampanii prezydenckiej w 2017 r. ${ }^{36}$ Przykłady te pokazują, jak istotną rolę może odgrywać w czasach obecnych przestrzeń informacyjna, która - jak pokazuje przypadek czeski - może realnie kształtować postawy i poglądy

31 Ławrow: całkowite wsparcie rosyjskiej diaspory to absolutny priorytet polityki zagranicznej Rosji, https://wpolityce.pl/swiat/270445-lawrow-calkowite-wsparcie-rosyjskiej-diaspory-to-absolutny-priorytetpolityki-zagranicznej-rosji (dostęp: 19.11.2017).

32 J. Darczewska, Rosyjskie siły zbrojne na froncie walki informacyjnej. Dokumenty strategiczne, „Prace OSW" 2016, nr 57, s. 11.

33 Czechy: rząd powołuje zespół do walki z kampania propagandowa Rosji, http://www.rp.pl/Polityka/161029832-Czechy-Rzad-powoluje-zespol-do-walki-z-kampania-propagandowa-Rosji.html (dostęp: 21.11.2017).

34 J. Darczewska, Anatomia rosyjskiej wojny informacyjnej. Operacja krymska - studium przypadku, „Punkt widzenia OSW” 2014, nr 42, s. 35.

35 M. Krakowska, Holandia walczy z rosyjska propaganda, https://sztab.org/polska-pomoze-holandii-walce-rosyjska-propaganda/ (dostęp: 7.02.2018).

36 We Francji ruszył rosyjski kanat telewizyjny Russia Today, http://wiadomosci.dziennik.pl/media/ artykuly/564956,l-express-we-francji-ruszyl-rosyjski-kanal-telewizyjny-rt.html (dostęp: 7.02.2018). 
obywateli. Przestrzeń ta - jako jeden z elementów wykorzystania tzw. miękkiej siły przez Rosję - będzie odgrywać coraz istotniejszą rolę w kreowaniu polityki zagranicznej.

\section{Podsumowanie}

Analizując powyższe przypadki, można stwierdzić, iż znaczenie określonych rodzajów przestrzeni w dziejach Rosji ulegało zmianie. W przeszłości istotne były zarówno materialne typy tego zjawiska, jak i ich niematerialne odpowiedniki. Szczególną doniosłość należy przypisać przestrzeni fizycznej, odgrywającej ważną rolę na polu polityki wewnętrznej i zagranicznej. Służyła ona poszerzaniu granic państwa, implikując przez to rozszerzanie jego strefy wpływów, i pozwalała jednocześnie na wzrost poziomu bezpieczeństwa wewnętrznego. Wśród przestrzeni niematerialnych niezwykle istotne miejsce zajmowały zwłaszcza przestrzeń ekonomiczna oraz społeczna, gdyż ich poszerzanie lub utwierdzenie było częstym imperatywem, zachęcającym rosyjskich decydentów do podjęcia określonych działań na arenie wewnętrznej (np. rozwiązanie problemów demograficznych) bądź międzynarodowej (rozwój gospodarczy).

Obecnie kształtowanie najważniejszych dróg rozwoju polityki rosyjskiej zdominowały przestrzenie niematerialne, zwłaszcza w zakresie polityki zagranicznej. Rosja poszerza swoje wpływy gospodarcze oraz kulturowe, chcąc być odbierana jako atrakcyjny partner, z którym współpraca przynosi wymierne korzyści. W celu umocnienia swojej pozycji intensywnie wykorzystuje przestrzeń informacyjną, będącą dzisiaj podstawowym narzędziem wymiany informacji oraz kreacji wizerunku.

Jednakże za typ przestrzeni, który odegrał najistotniejszą rolę w kształtowaniu polityki Rosji, uznać można przestrzeń konceptualną. Wszystkie przedstawione w artykule działania podejmowane były w celu realizacji pewnych idei, powstałych poprzez lokalizowanie oraz hierarchizację wartości, takich jak: rozwój ekonomiczny, zapobieżenie nadmiernemu przeludnieniu, bezpieczeństwo państwa. Opisane przestrzenie były albo narzędziem, albo rezultatem realizacji określonych założeń konceptualnych.

Jedną z przestrzeni, która w opisy wanym przypadku została wykorzystana w charakterze narzędzia urzeczywistnienia przestrzeni konceptualnej, była przestrzeń fizyczna. Rozrost terytorialny, wyrażany w postaci podbojów lub tworzenia stref buforowych, miał na celu realizację idei maksymalnej ochrony granic państwa, narażonych na ciągłe naruszanie. W podobnym charakterze używana jest obecnie przestrzeń informacyjna — dzięki odpowiedniemu posługiwaniu się nią Rosja jest w stanie wpływać na politykę innych państw, kształtując informacje w sposób dla siebie korzystny i oddziałujący na postawy i poglądy.

W wyniku wdrażania ukształtowanych na gruncie przestrzeni konceptualnej idei tworzone były inne rodzaje tego zjawiska, jak: przestrzeń symboliczna, społeczna, ekonomiczna czy organizacyjna. Przestrzeń konceptualna w opisywanym przypadku odebrana może być jako swoisty punkt wyjścia powstania, funkcjonowania oraz wynikania wzajemnych relacji między nimi. Zawiera ona w sobie wszystkie inne przestrzenie, $w$ tym 
pragmatyczną, przyjmującą w procesie jej kreowania różne postacie, m.in. wspomniane wyżej rodzaje. W jej ramach przestrzenie pokrywają się z sobą, tworząc finalny obraz opisywanego procesu.

Paralelnie do zmniejszającej się roli przestrzeni materialnych można zaobserwować radykalną zmianę ich statusu, szczególnie w przypadku przestrzeni fizycznej, która z będącego niegdyś jednym z głównych elementów przyczyniających się do rozwoju państwa stała się czynnikiem obciążającym go oraz hamującym rozwój wewnętrzny. Syberia jest obecnie dla Rosji źródłem jej najważniejszego dochodu, czyli surowców naturalnych, co czyni jednak z Moskwy tradycyjne państwo rentierskie, niedążące do dywersyfikacji gospodarki i działań modernizacyjnych ${ }^{37}$. Innym problemem Moskwy jest wyraźny brak pomysłu na zagospodarowanie wielkich przestrzeni. Przykładem złej decyzji dotyczącej planowania przestrzennego jest lokalizacja ośrodków przemysłowych na Syberii. Ogromne odległości między nimi i niesprzyjający klimat generują ogromne koszty produkcji i utrzymania połączeń ${ }^{38}$. Rezultatem nietrafionych decyzji planistycznych jest stopniowe wyludnianie się syberyjskich regionów. Wielkość terytorialna Rosji stanowi znaczącą przeszkodę dla możliwych działań realizowanych także w zakresie polityki zagranicznej, gdyż Moskwa ze swoim wielkim potencjałem albo jest zmuszona przyjąć rolę lidera (jak w wypadku EUG), albo jest partnerem zbyt dużym dla możliwych procesów współpracy ${ }^{39}$.

Odwrotną zależność zauważyć można w przypadku przestrzeni niematerialnych, które zdecydowanie zdominowały najważniejsze kierunki rozwoju rosyjskiej polityki. W przyszłości najważniejszą rolę odgrywać mogą przestrzenie: ekonomiczna i informacyjna, gdyż Rosja swój potencjał opiera przede wszystkim na zwiększaniu swojej gospodarczej siły oraz utwierdzaniu dominacji nad krajami wchodzącymi w orbitę jej wpływów.

Reasumując, w zależności od różnych aspektów procesu kształtowania polityki Rosji czynnik przestrzenny odgrywał zawsze jedną z dominujących ról. Przestrzeń była jednym z najważniejszych determinant przebiegu i rezultatu podejmowanych działań. Jednakże najistotniejszą rolę pełniła bez wątpienia w opisywanym przypadku przestrzeń konceptualna - główny impuls pozwalający na skonkretyzowanie oraz wdrożenie określonych aspektów rozwoju Rosji.

\section{Bibliografia}

Aksenov K.E., Prostranstvo i politika. Konceptualnyje podchody i izuczienije osobnoi priedmietnoi oblasti, Petropolis, Sankt Petersburg 1993.

Andrusieczko P., Problem Krymu w relacjach rosyjsko-ukraińskich, [w:] Rosja. Między imperium a mocarstwem nowoczesnym, red. A. Dudek, R. Mazur, Adam Marszałek, Toruń 2010.

37 A. Łukasiewicz, Kondycja ekonomiczna Rosji w nowym stuleciu, „Analizy Centrum Stosunków Międzynarodowych" 2015, nr 9, s. 4-5.

38 P. Buhler, O potędze w XXI wieku, Warszawa 2014, s. 181-182.

39 A. Legucka, Postrzeganie przestrzeni jako bariery modernizacyjnej Rosji, [w:] Bariery modernizacji Rosji, red. S. Bieleń, A. Skrzypek, Warszawa 2014, s. 155. 
Bierdajew M., O władzy przestrzeni nad rosyjska dusza, [w:] Niemarksistowska filozofia rosyjska. Antologia tekstów filozoficznych XIX i pierwszej połowy XX wieku. Część I, red. L. Kiejzik, Ibidem, Łódź 2011.

Buhler P., O potędze w XXI wieku, Wydawnictwo Akademickie Dialog, Warszawa 2014.

Bukowski A., Lubaś M., Nowak J., Społeczne tworzenie miejsc - globalizacja, etniczność, władza, Wydawnictwo Uniwersytetu Jagiellońskiego, Kraków 2010.

Butler Ch., Critical legal studies and the politics of space, „Social and Legal Studies” 18, 2009, nr 3.

Curanovic A., Dyplomacja konfesyjna Federacji Rosyjskiej, [w:] Rosja. Między imperium a mocarstwem nowoczesnym, red. A. Dudek, R. Mazur, Adam Marszałek, Toruń 2010.

Czechy: rząd powołuje zespół do walki z kampanią propagandowa Rosji, http://www.rp.pl/Polityka/161029832-Czechy-Rzad-powoluje-zespol-do-walki-z-kampania-propagandowa-Rosji.html (dostęp: 21.11.2017).

Darczewska J., Anatomia rosyjskiej wojny informacyjnej. Operacja krymska - studium przypadku „Punkt widzenia OSW" 2014, nr 42.

Darczewska J., Rosyjskie siły zbrojne na froncie walki informacyjnej. Dokumenty strategiczne, „Prace OSW” 2016, nr 57.

Etkind A., Internal Colonization: Russia's Internal Experience, Wlilley, Cambridge 2011.

Fryer P., Heaven, Hell or...? Something in between? Contrasting Russia Images of Syberia, [w:] Beyond the Limits. The Concept of Space in Russian History and Culture, red. J. Smith, Suomen Historialinen Seura, Helsinki 1999.

Gałganek A., Przestrzenny obraz świata w nauce o stosunkach międzynarodowych, „Sprawy Międzynarodowe" 1989, nr 3.

Harvey D., Space as a key word, referat wygłoszony na Marx and Philosophy Conference 20 maja 2004 w Institute of Education w Londynie, dostępny na stronie http://www.frontdeskapparatus.com/files/ harvey2004.pdf (dostęp: 6.02.2018).

Jastrzębska O., Geoekonomiczne motywy działania Rosji względem Ukrainy, „Ante Portas. Studia nad Bezpieczeństwem" 2015, nr 2 (5).

Javeau C., Przestrzeń jako forma społeczna, forma życia, próba odnowienia koncepcji według R. Lerduta, A. Schutza i G. Simmla, [w:] Przestrzeń znacząca. Studia socjologiczne, red. J. Wódz, Śląski Instytut Naukowy, Katowice 1989.

Kaplan R., The Revenge of Geography. What the Map Tells Us about Conflicts and the Battle against Fate, Random House, Toronto 2012.

Kosienkowski M., Strategia adaptacyjna Federacji Rosyjskiej wobec państw bałtyckich, Adam Marszałek, Toruń 2006.

Krakowska M., Holandia walczy z rosyjska propaganda, https://sztab.org/polska-pomoze-holandii-walce-rosyjska-propaganda/ (dostęp: 7.02.2018).

Kublik A., Premierem Armenii został menadżer Gazpromu, http://wyborcza.pl/1,155290,20685257,premierem-armenii-zostal-menedzer-gazpromu.html (dostęp: 20.11.2017).

Legucka A., Postrzeganie przestrzeni jako bariery modernizacyjnej Rosji, [w:] Bariery modernizacji Rosji, red. S. Bieleń, A. Skrzypek, Oficyna Wydawnicza ASPRA - JR, Warszawa 2014.

Lincoln W.B., The Conquest of the Continent: Siberia and the Russians, Cornell University Press, Ithaca 2007.

Lisowski A., Typy przestrzeni a geografia, „Prace Komisji Obszaru Krajobrazu Kulturowego” 2014, nr 24.

Ławrow: calkowite wsparcie rosyjskiej diaspory to absolutny priorytet polityki zagranicznej Rosji, https:// wpolityce.pl/swiat/270445-lawrow-calkowite-wsparcie-rosyjskiej-diaspory-to-absolutny-priorytetpolityki-zagranicznej-rosji (dostęp: 19.11.2017).

Łożeński M., Ekspansja na wszystkich azymutach: od Rurykowiczów po gesneków, Wyzwolenie, Warszawa 1987.

Łukasiewicz A., Kondycja ekonomiczna Rosji w nowym stuleciu, „Analizy Centrum Stosunków Międzynarodowych" 2015, nr 9.

Marasanova W.M., Istorija Rossiji do konca XVII stoletija, Rosspen, Moskwa 2013.

Massey D., Politics and space/time, „New Left Review” 1992, I/196. 
Medvedev S.A., General Theory of Russian Space: A Gay Science and the Rigorous Science, [w:] Beyond the Limits. The Concept of Space in Russian History and Culture, red. J. Smith, Suomen Historialinen Seura, Helsinki 1999.

Mejer A., Socjologia i przestrzeń miejska, Wydawnictwo Naukowe PWN, Warszawa 2010.

Michalik A., Unia Eurazjatycka - realną szansq dla integracji gospodarczej w regionie, „Studia Ekonomiczne. Zeszyty Naukowe UE w Katowicach” 2015, nr 228.

Pawlikowski G., Mniejszość rosyjska jako instrument polityki zagranicznej Federacji Rosyjskiej po 1991 roku, http:/geopolityka.net/grzegorz-pawlikowski-mniejszosc-rosyjska-jako-instrument-polityki-zagranic znej-federacji-rosyjskiej (dostęp: 1.01.2018).

Remnev A., Siberia and the Russian Far East in the Imperial Geography of Power, [w:] J. Burbank, M. von Hagen, A.V. Remnev, Russian Empire: Space, People, Power, Indiana University Press, Bloomington 2007.

Rogov W.J., Osnovy formirovanija geoekonomiczieskich regionov sovriemiennoi Rossiji, BGUZEP, Irkutsk 2002.

Roskal Z.E., Koncepcje przestrzeni w filozofii przyrody, „Roczniki Filozoficzne” 56, 2008, nr 1.

Świeżak P., Unia Celna - między mirażem "Wschodniej Unii Europejskiej” a widmem „nowego ZSRR”, „Bezpieczeństwo Narodowe” 2013, nr 28.

We Francji ruszył rosyjski kanat telewizyjny Russia Today, http://wiadomosci.dziennik.pl/media/artykuly /564956,l-express-we-francji-ruszyl-rosyjski-kanal-telewizyjny-rt.html (dostęp: 7.02.2018).

Zajączkowski W., Rosja i narody. Ósmy kontynent. Szkic dziejów Eurazji, Wydawnictwo MG, Warszawa 2015.

\section{Space and it's role in creating Russian statehood}

Keywords: space, buffer zones, colonization, territorial expansion

\section{Summary}

The main intention of this article is to present the role of space as one of the major factors, which constituted Russian statehood and it's role on international scene. This phenomena, which can be understand not only in the psychical frame, had big influence on shaping the foreign and internal policy of this state. As the fundamental of this process can be seen the specific attitude to space, which characterized Russians and considered this phenomena as mighty power, which can influence the social and political occurrences. The article also tried to investigate which role in creating Russia's position space has in current times - it develops or inhibits Russia? 